\title{
Cutaneous Manifestation as Initial Presentation of Metastatic Breast Cancer: A Systematic Review
}

\author{
Cassandra Johnson, DO; Daniel P. Friedmann, MD; Anita Gade, DO; Naveen Dhawan, MBA; \\ Kathryn Hinchee-Rodriguez, PhD; Vineet Mishra, MD; Sofia Rodriguez, DO; Matthew Apicella, DO
}

\section{PRACTICE POINTS}

- Dermatologists may play a role in diagnosing breast cancer through cutaneous metastasis, even in patients without a history of breast cancer.

- Clinicians should consider breast cancer metastasis in the differential for any erythematous lesion on the trunk.

\begin{abstract}
Metastatic breast cancer initially may present with cutaneous lesions. The goal of this systematic review was to evaluate available reports where the initial discovery of primary breast cancer occurred through the diagnosis of metastatic cutaneous lesions. We aimed to better understand these cases and the role of dermatologists in their diagnosis. A review of the literature for case reports and retrospective studies was conducted using the following databases: MEDLINE/PubMed, EMBASE, Cochrane library, CINAHL, and EBSCO. The PRISMA guidelines were utilized. Studies were included if they reported a cutaneous metastasis of a primary breast cancer in females. Studies were excluded if skin metastasis occurred in a patient with a history of breast cancer. Thirty-six publications were identified. Among these, 27 were case reports, and 9 were retrospective reviews. An enhanced understanding of how these cutaneous metastases present may be of clinical benefit to physicians, particularly dermatologists.
\end{abstract}

Cutis. 2021;107:E29-E36.

B reast cancer is the second most common malignancy in women (after primary skin cancer) and is the second leading cause of cancer-related death in this population. In 2020, the American Cancer Society reported an estimated 276,480 new breast cancer diagnoses and 42,170 breast cancer-related deaths. ${ }^{1}$ Despite the fact that routine screening with mammography and sonography is standard, the incidence of advanced breast cancer at the time of diagnosis has remained stable over time, suggesting that life-threatening breast cancers are not being caught at an earlier stage. The number of breast cancers with distant metastases at the time of diagnosis also has not decreased. ${ }^{2}$ Therefore, although screening tests are valuable, they are imperfect and not without limitations.

Cutaneous metastasis is defined as the spread of malignant cells from an internal neoplasm to the skin, which can occur either by contiguous invasion or by distant metastasis through hematogenous or lymphatic routes. ${ }^{3}$ The diagnosis of cutaneous metastasis requires a high index of suspicion on the part of the clinician. ${ }^{4}$ Of the various internal malignancies in women, breast cancer most frequently results in metastasis to the skin, ${ }^{5}$ with up to $24 \%$ of patients with metastatic breast cancer developing cutaneous lesions. ${ }^{6}$

In recent years, there have been multiple reports of skin lesions prompting the diagnosis of a previously unknown breast cancer. In a study by Lookingbill et al, ${ }^{6}$ $6.3 \%$ of patients with breast cancer presented with cutaneous involvement at the time of diagnosis, with 3.5\% having skin symptoms as the presenting sign. Although there have been studies analyzing cutaneous metastasis from various internal malignancies, none thus far have focused on cutaneous metastasis as a presenting sign of breast cancer. This systematic review aimed to highlight

Drs. Johnson, Hinchee-Rodriguez, and Apicella and Mr. Dhawan are from Nova Southeastern University, Fort Lauderdale, Florida. Dr. Friedmann is from Westlake Dermatology Clinical Research Center, Austin, Texas. Dr. Gade is from the New York Institute of Technology College of Osteopathic Medicine, Old Westbury, New York. Dr. Mishra is from University of Texas Health San Antonio. Dr. Rodriguez is from the Long School of Medicine, University of Texas Health San Antonio.

The authors report no conflict of interest.

Correspondence: Cassandra Johnson, DO, 3296 SW 76th Ave, Davie, FL 33314 (cass.ufl@gmail.com). doi:10.12788/cutis.0223 
the diverse clinical presentations of cutaneous metastatic breast cancer and their clinical implications.

\section{Methods}

Study Selection-This study utilized the PRISMA guidelines for systematic reviews. ${ }^{7}$ A review of the literature was conducted using the following databases: MEDLINE/PubMed, EMBASE, Cochrane library, CINAHL, and EBSCO.

Search Strategy and Analysis-We completed our search of each of the databases on December 16, 2017, using the phrases cutaneous metastasis and breast cancer to find relevant case reports and retrospective studies. Three authors (C.J., S.R., and M.A.) manually reviewed the resulting abstracts. If an abstract did not include enough information to determine inclusion, the full-text version was reviewed by 2 of the authors (C.J. and S.R.). Two of the authors (C.J. and M.A.) also assessed each source for relevancy and included the articles deemed eligible (Figure 1).

Inclusion criteria were the following: case reports and retrospective studies published in the prior 10 years (January 1, 2007, to December 16, 2017) with human female patients who developed metastatic cutaneous lesions due to a previously unknown primary breast malignancy. Studies published in other languages were included; these articles were translated into English using a human translator or computer translation program (Google Translate). Exclusion criteria were the following: male patients, patients with a known diagnosis of primary breast malignancy prior to the appearance of a metastatic cutaneous lesion, articles focusing on the treatment of breast cancer, and articles without enough details to draw meaningful conclusions.

For a retrospective review to be included, it must have specified the number of breast cancer cases and the number of cutaneous metastases presenting initially or simultaneously to the breast cancer diagnosis. Bansal et $\mathrm{al}^{8}$ defined a simultaneous diagnosis as a skin lesion presenting with other concerns associated with the primary malignancy.

\section{Results}

The initial search of MEDLINE/PubMed, EMBASE, Cochrane library, CINAHL, and EBSCO yielded a total of 722 articles. Seven other articles found separately while undergoing our initial research were added to this total. Abstracts were manually screened, with 657 articles discarded after failing to meet the predetermined inclusion criteria. After removal of 25 duplicate articles, the full text of the remaining 47 articles were reviewed, leading to the elimination of an additional 11 articles that did not meet the necessary criteria. This resulted in 36 articles (Figure 1), including 27 individual case reports (Table 1) and 9 retrospective reviews (Table 2).

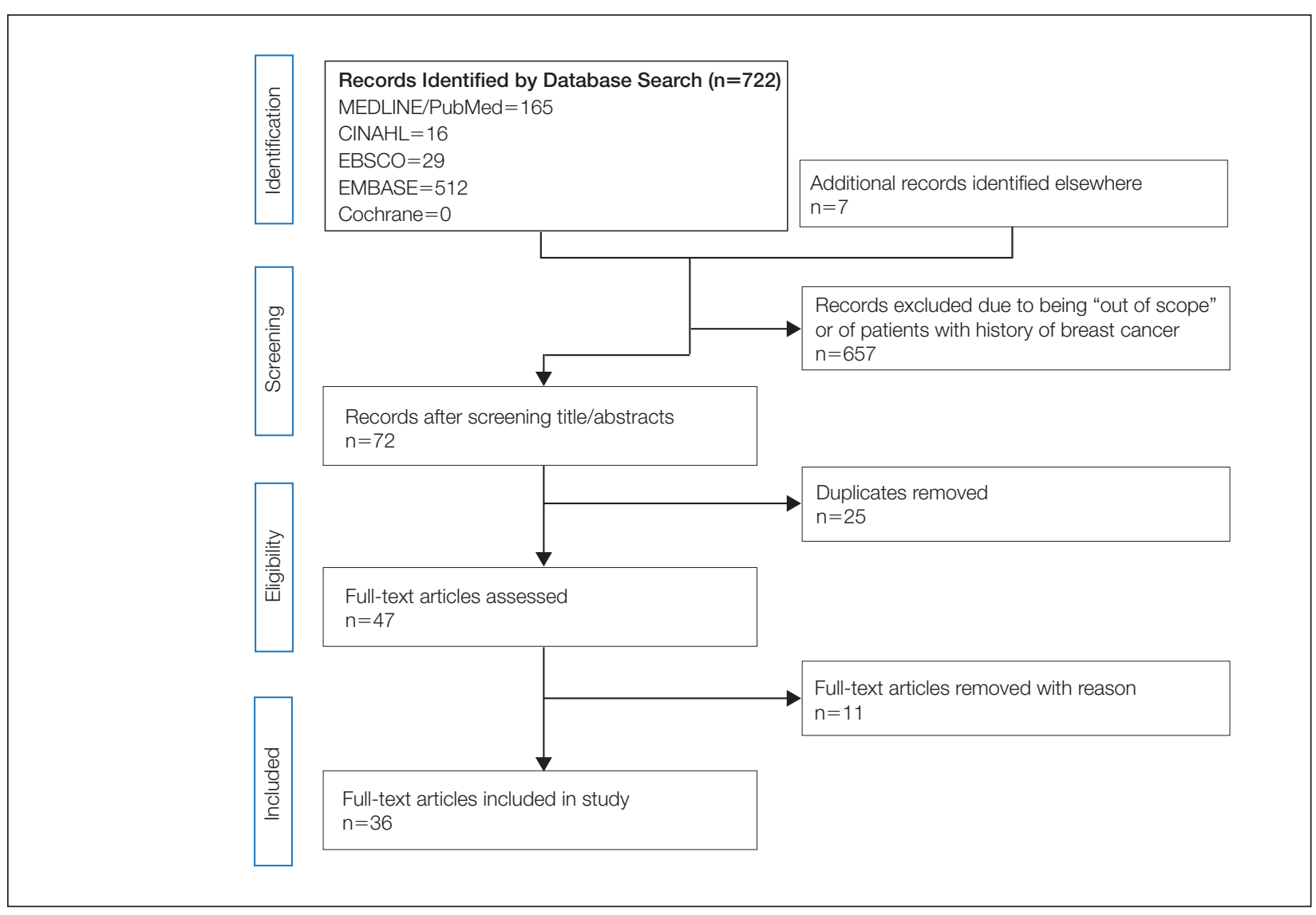

FIGURE 1. Diagram depicting study flow. 
TABLE 1. Cutaneous Lesion Appearance for Each Case Report

\begin{tabular}{|c|c|}
\hline Reference & Cutaneous lesion appearance \\
\hline Ahmed $^{9}$ & Edematous rash on chest and neck with generalized thickening on breast \\
\hline Alani et $a^{10}$ & Erythematous, indurated, ulcerated plaques with sharp demarcation \\
\hline Al Ameer et al ${ }^{11}$ & Multiple erythematous macules and plaques on breast \\
\hline Bhattacharyya et al ${ }^{12}$ & Erythematous plaques with crusting, oozing, and indurated margins \\
\hline Carlos Ortega et $\mathrm{al}^{13}$ & Multiple erythematous nodules on face, neck, trunk, and abdomen \\
\hline Chandanwale et $\mathrm{al}^{14}$ & $\begin{array}{l}\text { Multiple erythematous and papulovesicular linear lesions on the right chest along the } \\
\text { T2-T3 dermatome }\end{array}$ \\
\hline Cullen Aravena et $\mathrm{al}^{15}$ & $\begin{array}{l}\text { Multiple erythematous violaceous plaques on the chest wall, shoulder, arm, and scapular region with a } \\
\text { carcinoma en cuirasse appearance }\end{array}$ \\
\hline Damaskos et al ${ }^{2}$ & Multiple erythematous, $0.5-\mathrm{mm}$, urticarial lesions \\
\hline Frances et al ${ }^{16}$ & Polychromatic, multilobulated, cystic-appearing nodule on nipple \\
\hline Gaitan-Gaona et al ${ }^{17}$ & Single ulcerated, 3-cm black nodule below breast \\
\hline Goodier and Jordan ${ }^{18}$ & Single violaceous nodule on the right lower eyelid \\
\hline Lee et $\mathrm{al}^{19}$ & $\begin{array}{l}\text { Single erythematous mass protruding } 6 \mathrm{~cm} \text { with bloody discharge and crusting on left } \\
\text { anterior chest }\end{array}$ \\
\hline Mahore et $\mathrm{al}^{20}$ & $\begin{array}{l}\text { Anterior chest: multiple indurated small nodules extending to left axilla } \\
\text { Left arm: multiple keloidal indurated plaques }\end{array}$ \\
\hline Martí et $a^{21}$ & Single black, irregular, $\sim 1-\mathrm{cm}$ nodule on the occipital scalp \\
\hline Mehenni et al ${ }^{22}$ & Nodule resembling an angiomatous malformation of the lower eyelid \\
\hline O’Brien et $\mathrm{a}^{23}$ & Multiple lesions resembling dermatofibromas of the neck and chest \\
\hline O'Brien et $\mathrm{al}^{24}$ & Multiple erythematous, exophytic, friable nodules and swelling \\
\hline Oliveira et $\mathrm{al}^{25}$ & Scaly papulonodular lesions with a carcinoma en cuirasse appearance \\
\hline Salati and Rather ${ }^{26}$ & erythema and nodularity with scaling of the left breast, neck, axilla, a \\
\hline Santiago et $a^{27}$ & tiple erythematous, exophytic, papulonodular lesions \\
\hline Shagalov et $\mathrm{al}^{5}$ & Pink-brown, rubbery, indurated, 4-cm plaque in the right axilla \\
\hline Siqueira et $\mathrm{al}^{28}$ & Single erythematous indurated plaque with central retraction on the intermammary region \\
\hline Uria et $\mathrm{al}^{29}$ & Multiple erythematous, 0.5 - to 1 -cm papules on the chest \\
\hline Virmani et $\mathrm{al}^{30}$ & Multiple erythematous, linear, vesicular papules along the T2-T3 dermatome in the axillary region \\
\hline $\begin{array}{l}\text { de Souza Weimann } \\
\text { et } \mathrm{al}^{31}\end{array}$ & Multiple flesh-colored, 0.3- to 1-cm nodules with a fibrous consistency on the axilla, chest, and back \\
\hline Wu et $\mathrm{al}^{32}$ & Single erythematous indurated nodule on the right middle finger \\
\hline Yaghoobi et $\left.a\right|^{33}$ & $\begin{array}{l}\text { Left breast: multiple violaceous, lymphangioma circumscriptum-like papulovesicular lesions } \\
\text { Right breast: multiple erythematous erysipelaslike lesions }\end{array}$ \\
\hline
\end{tabular}


Approximately $13.7 \%$ of patients in the 9 retrospective reviews presented with a skin lesion before or simultaneous to the diagnosis of breast cancer (Figure 2).

Forty-one percent (17/41) of the patients with cutaneous metastasis as a presenting feature of their breast cancer fell outside the age range for breast cancer screening recommended by the US Preventive Services Task Force, ${ }^{42}$ with $24 \%$ of the patients younger than 50 years and 17\% older than 74 years (Figure 3).

Lesion Characteristics - The most common cutaneous lesions were erythematous nodules and plaques, with a few reports of black ${ }^{17,21}$ or flesh-colored ${ }^{5,20,31}$ lesions, as well as ulceration. $8,17,32$ The most common location for skin lesions was on the thorax (chest or breast), accounting for $57 \%$ of the cutaneous metastases, with the arms and axillae being second most commonly involved (15\%) (Figure 4). Some cases presented with skin lesions extending to multiple regions. In these cases, each location of the lesion was recorded separately when analyzing the data. An additional 5 cases, shown as "Other" in Figure 4, included the eyelids, occiput, and finger. Eight case reports described symptoms associated with the cutaneous lesions, with painful or tender lesions reported in 7 cases $^{5,9,14,17,20,30,32}$ and pruritus in 2 cases. ${ }^{12,20}$ Moreover, 6 case reports presented patients denying any systemic or associated symptoms with their skin lesions. ${ }^{2,5,9,16,17,28}$ Multiple cases were initially treated as other conditions due to misdiagnosis, including herpes zoster $^{14,30}$ and dermatitis. ${ }^{11,12}$

Diagnostic Data-Eighteen cases reported positive immunohistochemistry from cutaneous biopsy (Table 3), given its high specificity in determining the origin of cutaneous metastases, while 8 case reports only performed hematoxylin and eosin staining. One case did not report hematoxylin and eosin or immunohistochemical

\section{TABLE 2. Characteristics and Content of Included Retrospective Reviews}

\begin{tabular}{|c|c|c|c|}
\hline Reference & Summary of study & $\begin{array}{l}\text { Total CMs } \\
\text { from breast }\end{array}$ & $\begin{array}{l}\text { Diagnosed before or simultaneous to } \\
\text { breast tumor }\end{array}$ \\
\hline Atis et $\mathrm{al}^{34}$ & $\begin{array}{l}\mathrm{CM} \text { patients seen at an outpatient } \\
\text { clinic in a } 6 \text {-y period; lesions examined } \\
\text { with histopathology }\end{array}$ & & $\begin{array}{l}\mathrm{n}=2 \text { diagnosed before (eczematous } \\
\text { plaques from ductal carcinoma primary) }\end{array}$ \\
\hline Bansal et $\mathrm{al}^{8}$ & $\begin{array}{l}\text { CM patients diagnosed by FNA in } \\
\text { a } 1-y \text { period; FNA found to be } \\
\text { highly sensitive and specific as a } \\
\text { diagnostic modality }\end{array}$ & $n=28$ & $\mathrm{n}=3$ diagnosed simultaneously \\
\hline Benmously et al ${ }^{35}$ & $\begin{array}{l}\text { CM patients seen at a dermatology } \\
\text { clinic in a 14-y period }\end{array}$ & $n=3$ & $\begin{array}{l}\mathrm{n}=2 \text { diagnosed before (third patient, } \\
\text { male, was excluded) }\end{array}$ \\
\hline Chopra et $\mathrm{al}^{36}$ & $\begin{array}{l}\text { Histopathologic specimens of CM } \\
\text { patients evaluated by a histopathology } \\
\text { laboratory in a } 5-y \text { period }\end{array}$ & $n=7$ & $\begin{array}{l}\mathrm{n}=2 \text { diagnosed simultaneously } \\
\text { (erythematous plaques from primary } \\
\text { ductal carcinoma) }\end{array}$ \\
\hline El Khoury et al ${ }^{37}$ & $\begin{array}{l}\text { CM patients seen at a university } \\
\text { medical center in an 8-y period; } \\
\text { lesions examined with histopathology }\end{array}$ & $\mathrm{n}=41$ & $\mathrm{n}=4$ diagnosed before \\
\hline Fernandez-Flores ${ }^{38}$ & $\begin{array}{l}\text { Histopathologic specimens of CM } \\
\text { patients evaluated by a pathology } \\
\text { department in a 13-y period }\end{array}$ & $n=22$ & $\mathrm{n}=9$ diagnosed simultaneously \\
\hline Gómez Sánchez et al ${ }^{39}$ & $\begin{array}{l}\text { CM patients diagnosed by histopathology } \\
\text { at a dermatology department in an } \\
18-y \text { period }\end{array}$ & $n=51$ & $\mathrm{n}=3$ diagnosed before \\
\hline Handa et $\mathrm{al}^{40}$ & $\begin{array}{l}\text { CM patients diagnosed by FNA in } \\
\text { a 9-y period }\end{array}$ & $n=23$ & $\mathrm{n}=1$ diagnosed before \\
\hline Itin and Tomaschett ${ }^{41}$ & $\begin{array}{l}\text { CM patients seen at a dermatology } \\
\text { department in a 6-y period }\end{array}$ & $\begin{array}{l}\mathrm{n}=18 \\
\text { (1 patient had } \\
2 \text { independent } \\
\text { breast cancers) }\end{array}$ & $\mathrm{n}=1$ diagnosed before \\
\hline
\end{tabular}

Abbreviations: CM, cutaneous metastasis; FNA, fine-needle aspiration. 


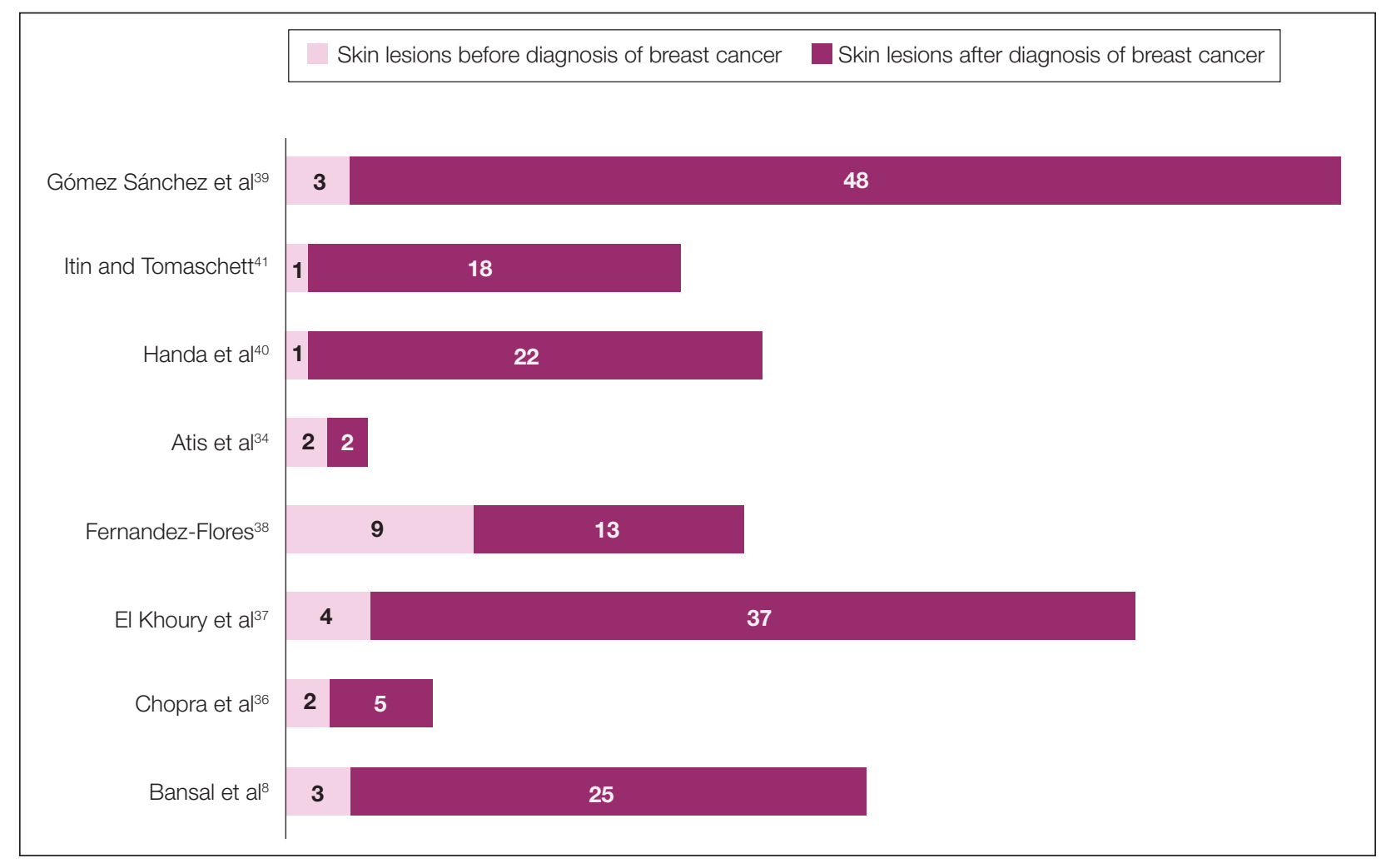

FIGURE 2. Summary of retrospective reviews comparing the number of skin lesions presenting as the primary finding of breast cancer.

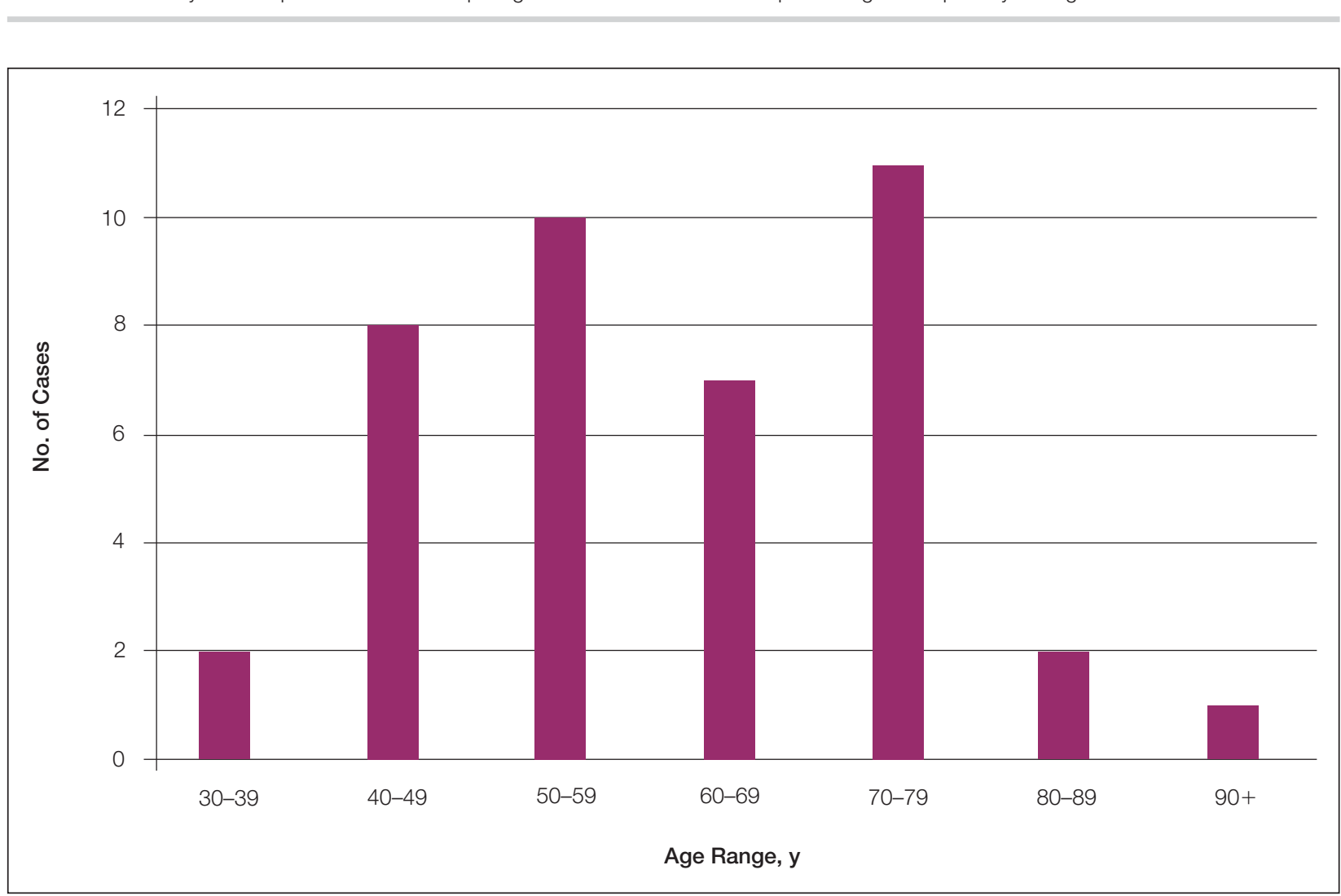

FIGURE 3. Number of reported cases by age group $(\mathrm{N}=41)$. 
FIGURE 4. Location of cutaneous metastasis as primary presentation of breast cancer $(\mathrm{N}=61)$.

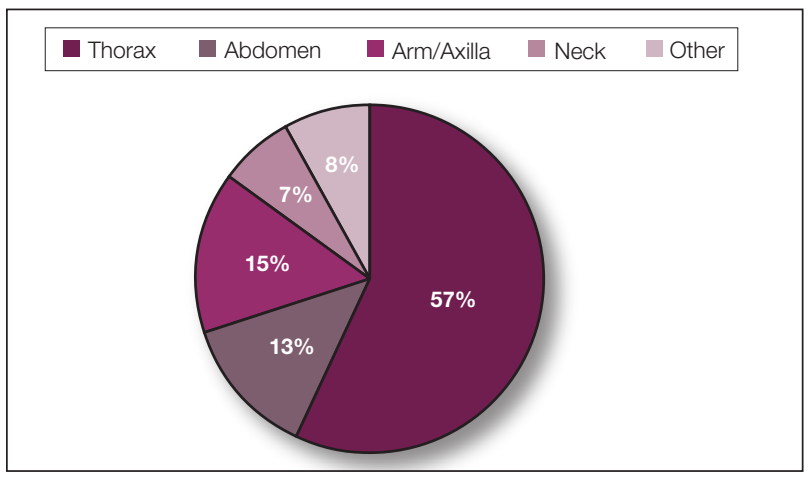

TABLE 3. Immunohistochemical Markers Reported in Each Case ${ }^{a}$

\begin{tabular}{|c|c|c|}
\hline \multirow[b]{2}{*}{ Reference } & \multicolumn{2}{|c|}{ Immunohistochemistry $^{\mathrm{a}}$} \\
\hline & Positive & Negative \\
\hline Alani et $\mathrm{al}^{10}$ & Strong positive: ER; weak positive: PR & \\
\hline Al Ameer et $a^{11}$ & AE1/AE3, CK7 & ER, PR \\
\hline Bhattacharyya et al ${ }^{12}$ & ER, GCDFP-15, AE1/AE3, CK7 & ND \\
\hline Carlos Ortega et $\mathrm{al}^{13}$ & ER, PR, GCDFP-15, EMA & ND \\
\hline Cullen Aravena et al ${ }^{15}$ & HER2, mammaglobin, AE1/AE3, CK & ER, PR, CK20 \\
\hline Damaskos et $\mathrm{al}^{2}$ & ER (all cells), PR (few cells) & ND \\
\hline Frances et $\mathrm{al}^{16}$ & ER, Bcl-2, E-cadherin & HER2, CK5-6, Ki-67, p63 \\
\hline Gaitan-Gaona et al17 & ER, PR & $\mathrm{HMB}-45$ \\
\hline Lee et $\mathrm{al}^{19}$ & ER, PR & ND \\
\hline Martí et $a^{21}$ & ER, AE1/AE3, EMA; melanocyte positive: HMB-45, Melan-A & ND \\
\hline Mehenni et al22 & Hormone receptor positive & ND \\
\hline O'Brien et $\mathrm{al}^{23}$ & $E R, P R, A E 1 / A E 3, C K 7$ & CK20, CD45, CD68, S100 \\
\hline Santiago et $\mathrm{al}^{27}$ & ER, CK7, CAM5.2 & PR, HER2 \\
\hline Shagalov et $\mathrm{al}^{5}$ & $\begin{array}{l}\mathrm{ER}, \mathrm{PR}, \mathrm{HER} 2 \text {, mammaglobin, AE1/AE3, GATA binding } \\
\text { protein 3, intracytoplasmic mucicarmine stain }\end{array}$ & E-cadherin \\
\hline Siqueira et $\mathrm{al}^{28}$ & ER, PR, mammaglobin, AE1/AE3, CK7, 34BE12 & $\mathrm{CDX} 2, \pi \mathrm{TF}-1$ \\
\hline Uria et $\mathrm{al}^{29}$ & GCPF-15, CK & LCA \\
\hline $\begin{array}{l}\text { de Souza Weimann } \\
\text { et } \mathrm{al}^{\mid 31}\end{array}$ & ER, mammaglobin, AE1/AE3, CK7 & $\begin{array}{l}\text { C-KIT, CK20, CD34, CDX2, WT1, LCA, } \\
\text { TIF-1, p63, S100 }\end{array}$ \\
\hline Wu et al ${ }^{32}$ & Strong positive: CK7, CK18; weak positive: PR, CEA & $\begin{array}{l}\text { ER, HER2, AFP, CA-125, TTF-1, NSE, } \\
\text { chromogranin A, synaptophysin, S100 }\end{array}$ \\
\hline \multicolumn{3}{|c|}{$\begin{array}{l}\text { Abbreviations: ER, estrogen receptor; PR, progesterone receptor; EGF, epidermal growth factor; CK, cytokeratin; GCDFP, gross cystic } \\
\text { disease fluid protein; ND, not determined; EMA, epithelial membrane antigen; HER2, human epidermal growth factor receptor } 2 \text {; } \\
\text { HMB, human melanoma black; TTF, thyroid transcription factor; LCA, leukocyte common antigen; AFP, alpha-fetoprotein; CEA, carcinoem- } \\
\text { bryonic antigen; NSE, neuron-specific enolase. } \\
\text { aThe following did not provide immunohistochemical information: Ahmed, }{ }^{9} \text { Chandanwale et al, }{ }^{14} \text { Goodier and Jordan, }{ }^{18} \text { Mahore et al, }{ }^{20} \\
\text { O'Brien et al, }{ }^{24} \text { Oliviera et al, }{ }^{25} \text { Salati and Rather, }{ }^{26} \text { Virmani et al, },^{30} \text { and Yaghoobi et al. }{ }^{33}\end{array}$} \\
\hline
\end{tabular}


TABLE 4. Final Breast Cancer Diagnosis for Each Case

\begin{tabular}{|c|c|}
\hline Reference & $\begin{array}{l}\text { Breast cancer } \\
\text { diagnosis }\end{array}$ \\
\hline Ahmed $^{9}$ & Adenocarcinoma \\
\hline Alani et $\mathrm{al}^{10}$ & Lobular breast carcinoma \\
\hline Al Ameer et $\mathrm{al}^{11}$ & $\begin{array}{l}\text { Inflammatory breast } \\
\text { carcinoma }\end{array}$ \\
\hline Bhattacharyya et al ${ }^{12}$ & Breast carcinoma \\
\hline Carlos-Ortega et al ${ }^{13}$ & Breast carcinoma \\
\hline Chandanwale et al ${ }^{14}$ & Breast carcinoma \\
\hline Cullen Aravena et al ${ }^{15}$ & Ductal breast carcinoma \\
\hline Damaskos et $\mathrm{al}^{2}$ & Lobular breast carcinoma \\
\hline Frances et $\mathrm{al}^{16}$ & Mucinous carcinoma \\
\hline Gaitan-Gaona et al17 & Ductal breast carcinoma \\
\hline Goodier and Jordan ${ }^{18}$ & Mucinous adenocarcinoma \\
\hline Lee et $\mathrm{al}^{19}$ & Ductal breast carcinoma \\
\hline Mahore et $\mathrm{al}^{20}$ & Ductal breast carcinoma \\
\hline Martí et $\mathrm{al}^{21}$ & Ductal breast carcinoma \\
\hline Mehenni et $\mathrm{al}^{22}$ & Lobular breast carcinoma \\
\hline O'Brien et $\mathrm{al}^{23}$ & Lobular breast carcinoma \\
\hline O'Brien et $\mathrm{a}^{24}$ & Lobular breast carcinoma \\
\hline Oliviera et $\mathrm{al}^{25}$ & Ductal breast carcinoma \\
\hline Salati and Rather ${ }^{26}$ & carcinoma \\
\hline Santiago et $\mathrm{al}^{27}$ & east carcinoma \\
\hline Shagalov et al ${ }^{5}$ & Lobular breast carcinoma \\
\hline Siqueira et $\mathrm{al}^{28}$ & Adenocarcinoma \\
\hline Uria et $\mathrm{al}^{29}$ & Lobular breast carcinoma \\
\hline Virmani et al ${ }^{30}$ & Breast carcinoma \\
\hline $\begin{array}{l}\text { de Souza Weimann } \\
\text { et } a^{131}\end{array}$ & Breast carcinoma \\
\hline Wu et al ${ }^{32}$ & Ductal breast carcinoma \\
\hline Yaghoobi et al ${ }^{33}$ & $\begin{array}{l}\text { Inflammatory breast } \\
\text { carcinoma }\end{array}$ \\
\hline
\end{tabular}

staining. Table 4 lists the final breast cancer diagnosis for each case.

As per the standard of care, patients were evaluated with mammography or ultrasonography, combined with fineneedle aspiration of a suspected primary tumor, to give a definitive diagnosis of breast cancer. However, 4 cases reported negative mammography and ultrasonography. ${ }^{13,22,28,31}$ In 3 of these cases, no primary tumor was ever found. ${ }^{13,22,31}$

\section{Comment}

Our systematic review demonstrated that cutaneous lesions may be the first clinical manifestation of an undetected primary malignancy. ${ }^{40}$ These lesions often occur on the chest but may involve the face, abdomen, or extremities. Although asymptomatic erythematous nodules and plaques are the most common clinical presentations, lesions may be tender or pruritic or may even resemble benign skin conditions, including dermatitis, cellulitis, urticaria, and papulovesicular eruptions, causing them to go unrecognized.

Nevertheless, cutaneous metastasis of a visceral malignancy generally is observed late in the disease course, often following the diagnosis of a primary malignancy. ${ }^{14}$ Breast cancer is the most common internal malignancy to feature cutaneous spread, with the largest case series revealing a $23.9 \%$ rate of cutaneous metastases in females with breast carcinoma. ${ }^{6}$ Because of its proximity, the chest wall is the most common location for cutaneous lesions of metastatic breast cancer.

Malignant cells from a primary breast tumor may spread to the skin via lymphatic, hematogenous, or contiguous tissue dissemination, as well as iatrogenically through direct implantation during surgical procedures. ${ }^{3}$ The mechanism of neoplasm spread may likewise influence the clinical appearance of the resulting lesions. The localized lymphedema with a peau d'orange appearance of inflammatory metastatic breast carcinoma or the erythematous plaques of carcinoma erysipeloides are caused by embolized tumor cells obstructing dermal lymphatic vessels.,11 On the other hand, the indurated erythematous plaques of carcinoma en cuirasse are caused by diffuse cutaneous and subcutaneous infiltration of tumor cells that also may be associated with marked reduction in breast volume. ${ }^{3}$

A primary breast cancer is classically diagnosed with a combination of clinical breast examination, radiologic imaging (ultrasound, mammogram, breast magnetic resonance imaging, or computed tomography), and fineneedle aspiration or lesional biopsy with histopathology. ${ }^{9}$ Given that in $20 \%$ of metastasized breast cancers the primary tumor may not be identified, a negative breast examination and imaging do not rule out breast cancer, especially if cutaneous biopsy reveals a primary malignancy. ${ }^{43}$ Histopathology and immunohistochemistry can thereby confirm the presence of metastatic cutaneous lesions and help characterize the breast cancer type involved, with adenocarcinomas being most commonly implicated. ${ }^{28}$ Although both ductal and lobular adenocarcinomas stain positive for cytokeratin 7 , estrogen 
receptor, progesterone receptor, gross cystic disease fluid protein 15, carcinoembryonic antigen, and mammaglobin, only the former shows positivity for e-cadherin markers. ${ }^{3}$ Conversely, inflammatory carcinoma stains positive for CD31 and podoplanin, telangiectatic carcinoma stains positive for CD31, and mammary Paget disease stains positive for cytokeratin 7 and mucin 1, cell surface associated. ${ }^{3}$ Apart from cutaneous biopsy, fine-needle aspiration cytology can likewise provide a simple and rapid method of diagnosis with high sensitivity and specificity. ${ }^{14}$

\section{Conclusion}

Although cutaneous metastasis as the presenting sign of a breast malignancy is rare, a high index of suspicion should be exercised when encountering rapid-onset, out-ofplace nodules or plaques in female patients, particularly nodules or plaques presenting on the chest.

\section{REFERENCES}

1. Siegel R, Miller K, Jemal A. Cancer statistics, 2020 [published online January 8, 2020]. CA Cancer J Clin. 2020;70:7-30.

2. Damaskos C, Dimitroulis D, Pergialiotis V, et al. An unexpected metastasis of breast cancer mimicking wheal rush. G Chir. 2016;37:136-138.

3. Alcaraz I, Cerroni L, Rütten A, et al. Cutaneous metastases from internal malignancies: a clinicopathologic and immunohistochemical review. Am J Dermatopathol. 2012;34:347-393.

4. Wong CYB, Helm MA, Kalb RE, et al. The presentation, pathology, and current management strategies of cutaneous metastasis. $N$ Am J Med Sci. 2013;5:499-504

5. Shagalov D, Xu M, Liebman T, et al. Unilateral indurated plaque in the axilla a case of metastatic breast carcinoma. Dermatol Online J. 2016;22:13030/ qt8vw382nx.

6. Lookingbill DP, Spangler N, Helm KF. Cutaneous metastases in patients with metastatic carcinoma: a retrospective study of 4020 patients. J Am Acad Dermatol. 1993;29:228-236.

7. Liberati A, Altman DG, Tetzlaff J, et al. The PRISMA statement for reporting systematic reviews and meta-analyses of studies that evaluate health care interventions: explanation and elaboration.J Clin Epidemiol. 2009;62:e1-e34.

8. Bansal R, Patel T, Sarin J, et al. Cutaneous and subcutaneous metastases from internal malignancies: an analysis of cases diagnosed by fine needle aspiration. Diagn Cytopathol. 2011;39:882-887.

9. Ahmed M. Cutaneous metastases from breast carcinoma. BMJ Case Rep. 2011;2011:bcr0620114398

10. Alani A, Roberts G, Kerr O. Carcinoma en cuirasse. BMJ Case Rep. 2017;2017:bcr2017222121.

11. Al Ameer A, Imran M, Kaliyadan F, et al. Carcinoma erysipeloides as a presenting feature of breast carcinoma: a case report and brief review of literature. Indian Dermatol Online J. 2015;6:396-398.

12. Bhattacharyya A, Gangopadhyay M, Ghosh K, et al. Wolf in sheep's clothing: a case of carcinoma erysipeloides. Oxf Med Case Rep. 2016;2016:97-100.

13. Carlos Ortega B, Alfaro Mejia A, Gómez-Campos G, et al. Metástasis de carcinoma de mama que simula prototecosis. Dermatol Rev Mex. 2012;56:55-61.

14. Chandanwale SS, Gore CR, Buch AC, et al. Zosteriform cutaneous metastasis: a primary manifestation of carcinoma breast, rare case report. Indian J Pathol Microbiol. 2011;54:863-864.

15. Cullen Aravena R, Cullen Aravena D, Velasco MJ, et al. Carcinoma hemorrhagiectoides: case report of an uncommon presentation of cutaneous metastatic breast carcinoma. Dermatol Online J. 2017;23:13030/qt3hm3z850.

16. Frances L, Cuesta L, Leiva-Salinas M, et al. Secondary mucinous carcinoma of the skin. Dermatol Online J. 2014;20:22361.

17. Gaitan-Gaona F, Said MC, Valdes-Rodriguez R. Cutaneous metastatic pigmented breast carcinoma. Dermatol Online J. 2016;22:13030/ qt0sv018ck.

18. Goodier MA, Jordan JR. Metastatic breast cancer to the lower eyelid. Laryngoscope. 2010;120(suppl 4):S129.
19. Lee H-J, Kim J-M, Kim G-W, et al. A unique cutaneous presentation of breast cancer: a red apple stuck in the breast. Ann Dermatol. 2016;28:499-501.

20. Mahore SD, Bothale KA, Patrikar AD, et al. Carcinoma en cuirasse : a rare presentation of breast cancer. Indian J Pathol Microbiol. 2010;53:351-358.

21. Martí N, Molina I, Monteagudo C, et al. Cutaneous metastasis of breast carcinoma mimicking malignant melanoma in scalp. Dermatol Online J. 2008;14:12.

22. Mehenni NN, Gamaz-Bensaou M, Bouzid K. Metastatic breast carcinoma to the gallbladder and the lower eyelid with no malignant lesion in the breast: an unusual case report with a short review of the literature [abstract]. Ann Oncol. 2013;24(suppl 3):iii49.

23. O'Brien OA, AboGhaly E, Heffron C. An unusual presentation of a common malignancy [abstract]. J Pathol. 2013;231:S33.

24. O'Brien R, Porto DA, Friedman BJ, et al. Elderly female with swelling of the right breast. Ann Emerg Med. 2016;67:e25-e26.

25. Oliveira GM de, Zachetti DBC, Barros HR, et al. Breast carcinoma en Cuirasse_case report. An Bras Dermatol. 2013;88:608-610.

26. Salati SA, Rather AA. Carcinoma en cuirasse. J Pak Assoc Derma. 2013; 23:452-454.

27. Santiago F, Saleiro S, Brites MM, et al. A remarkable case of cutaneous metastatic breast carcinoma. Dermatol Online J. 2009;15:10.

28. Siqueira VR, Frota AS, Maia IL, et al. Cutaneous involvement as the initial presentation of metastatic breast adenocarcinoma - case report. An Bras Dermatol. 2014;89:960-963.

29. Uria M, Chirino C, Rivas D. Inusual clinical presentation of cutaneous metastasis from breast carcinoma. A case report. Rev Argent Dermatol. 2009;90:230-236.

30. Virmani NC, Sharma YK, Panicker NK, et al. Zosteriform skin metastases: clue to an undiagnosed breast cancer. Indian J Dermatol. 2011;56:726-727.

31. de Souza Weimann ET, Botero EB, Mendes C, et al. Cutaneous metastasis as the first manifestation of occult malignant breast neoplasia. An Bras Dermatol. 2016;91(5 suppl 1):105-107.

32. Wu CY, Gao HW, Huang WH, et al. Infection-like acral cutaneous metastasis as the presenting sign of an occult breast cancer. Clin Exp Dermatol. 2009;34:e409-e410.

33. Yaghoobi R, Talaizade A, Lal K, et al. Inflammatory breast carcinoma presenting with two different patterns of cutaneous metastases: carcinoma telangiectaticum and carcinoma erysipeloides. J Clin Aesthet Dermatol. 2015;8:47-51.

34. Atis G, Demirci GT, Atunay IK, et al. The clinical characteristics and the frequency of metastatic cutaneous tumors among primary skin tumors. Turkderm. 2013;47:166-169.

35. Benmously R, Souissi A, Badri T, et al. Cutaneous metastases from internal cancers. Acta Dermatovenerol Alp Pannonica Adriat. 2008;17:167-170.

36. Chopra R, Chhabra S, Samra SG, et al. Cutaneous metastases of internal malignancies: a clinicopathologic study. Indian J Dermatol Venereol Leprol. 2010;76:125-131.

37. El Khoury J, Khalifeh I, Kibbi AG, et al. Cutaneous metastasis: clinicopathological study of 72 patients from a tertiary care center in Lebanon. Int J Dermatol. 2014;53:147-158.

38. Fernandez-Flores A. Cutaneous metastases: a study of 78 biopsies from 69 patients. Am J Dermatopathol. 2010;32:222-239.

39. Gómez Sánchez ME, Martinez Martinez ML, Martín De Hijas MC, et al. Metástasis cutáneas de tumores sólidos. Estudio descriptivo retrospectivo. Piel. 2014;29:207-212.

40. Handa U, Kundu R, Dimri K. Cutaneous metastasis: a study of 138 cases diagnosed by fine-needle aspiration cytology. Acta Cytol. 2017;61:47-54.

41. Itin $\mathrm{P}$, Tomaschett $\mathrm{S}$. Cutaneous metastases from malignancies which do not originate from the skin. An epidemiological study. Article in German. Internist (Berl). 2009;50:179-186.

42. Siu AL, U.S. Preventive Services Task Force. Screening for breast cancer: U.S. Preventive Services Task Force recommendation statement. Ann Intern Med. 2016;164:279-296.

43. Torres HA, Bodey GP, Tarrand JJ, et al. Protothecosis in patients with cancer: case series and literature review. Clin Microbiol Infect. 2003;9:786-792. 